\title{
Cycles and rhythms within the Boda Claystone Formation in WELL Ib-4
}

Amadé Halász

Institute of Environmental Science, University of Pécs, Pécs

The present cycle-stratigraphic study is based on four main alternating lithofacies of the Boda Claystone Formation (sandstone, siltstone, claystone and dolomite). The statistical analysis of cycles/rhythms identified from the main rock types of the sequence showed that the theoretical cycle is a succession made up of all layer types and contains the entire sandstone-dolomite row. The definition of the modal cycles that are closer to reality and to practical applications was carried out in several steps. Because of changes within the formation, the modal cycle was identified separately within the major lithostratigraphic units. The more detailed analysis using seven rock types gave similar results, with the dominance of rhythms. Markov chain analysis indicates the arrangement of the Boda Formation in the form of fining-upward cycles. A complete cycle consists of sandstone or siltstone at the base sequentially succeeded by claystone and dolomite at the top. As a result two major facies transition successions can be identified from the facies relationships diagram, which are sandstone to claystone and dolomite to claystone transition. Unit One is represented by sandstone $(\mathrm{a}$, b) and siltstone (c, d), mainly occurring in the basal sequence. Unit Two is dominated by transition from sandstone (a) to silty sandstone (b) and (clayey) dolomite ( $g$, f) to siltstone (b) and/or claystone (e) facies transition successions.

Key words: Markov analysis, Upper Permian, Boda Claystone, Hungary, Mecsek

\section{Introduction}

Previous research (Hámos et al. 1996; Konrád 1999; Konrád and Hámos 2006) has shown that one of the potential host rocks for the disposal of high-level radioactive waste produced in Hungary is the Boda Claystone Formation (BCF). To specify the area appropriate for the establishment of the disposal facility it is

Address: A. Halász: H-7634 Pécs, Ifjúság út 6, Hungary; e-mail: tade@gamma.ttk.pte.hu Received: January 23, 2010; accepted: May 15, 2010 
necessary for the formation to be correlatable and the lithostratigraphic units to be traceable in the study area. Cycle-stratigraphic examinations can contribute to resolving the problem and they can also give a more detailed picture of the sedimentation process. The aim of the present paper is the cycle-stratigraphic study of the borehole Ib-4, drilled to study the BCF within the 5-year-long (20032008) mid-term research project by Mecsekérc Ltd. A partly numeric analysis of the cycles and rhythms building up the sequence was carried out. Due to the low number of previous cycle-stratigraphic examinations, only a few literature items are available on the topic. Jámbor (1964) was the first to mention the cyclic composition of the formation and to characterize this as uncertain; besides that, only three further papers contain cycle-stratigraphic analyses of the Boda Formation (Barabásné Stuhl 1969; Majoros 1998; Geiger 2005).

The fact that the formation cannot be dated exactly makes the work more difficult. Flora and fauna usable for dating is absent from the formation; thus the formation time of cycles/rhythms cannot be determined and only estimations can be made. Furthermore, the order of cycles in the formation is also impossible to define because of the dating problem.

When describing cycles, concepts presented by Balogh (1992) are used, the definition of which is also cited here.

- Theoretical cycle: a cyclic succession containing all beds (elements) and recorded during observation;

- Modal cycle: the most frequent cycle of the formation but not necessarily containing all elements;

- Ideal or model cycle: an idealized cycle defined following the analysis of cycles in the formation that describes the entire cyclic process;

- A unit built up of two or more members can also be an incomplete cycle. The difference between this and a rhythm is that here a part of the cycle was not deposited or was eroded;

- A rhythm has only two members due to the character of the sedimentation process.

\section{Geologic background}

The first to recognize the BCF as a separate stratigraphic unit was Barabás (C. Sc. dissertation, 1955). The BCF occurs in the Western Mecsek perianticline (Barabás 1955; Jámbor 1964), but it is also known in a very thin and atypical form within the Permian sequence of the Nagykozár-2 (Nk-2) and Máriakéménd-3 (Mk-3) boreholes (Fig. 1), together with the typical under- and overlying formations (boreholes Nk-2, Mk-3, in a thickness of 6.3 and $18.2 \mathrm{~m}$, respectively) (Barabásné Stuhl 1988).

The rock is usually thick-bedded or shows nodular-granular weathering. Its color is reddish-brown or brownish-red; the sandstone interbeds are of similar tone but usually lighter. The dolomite is white. According to the results of 


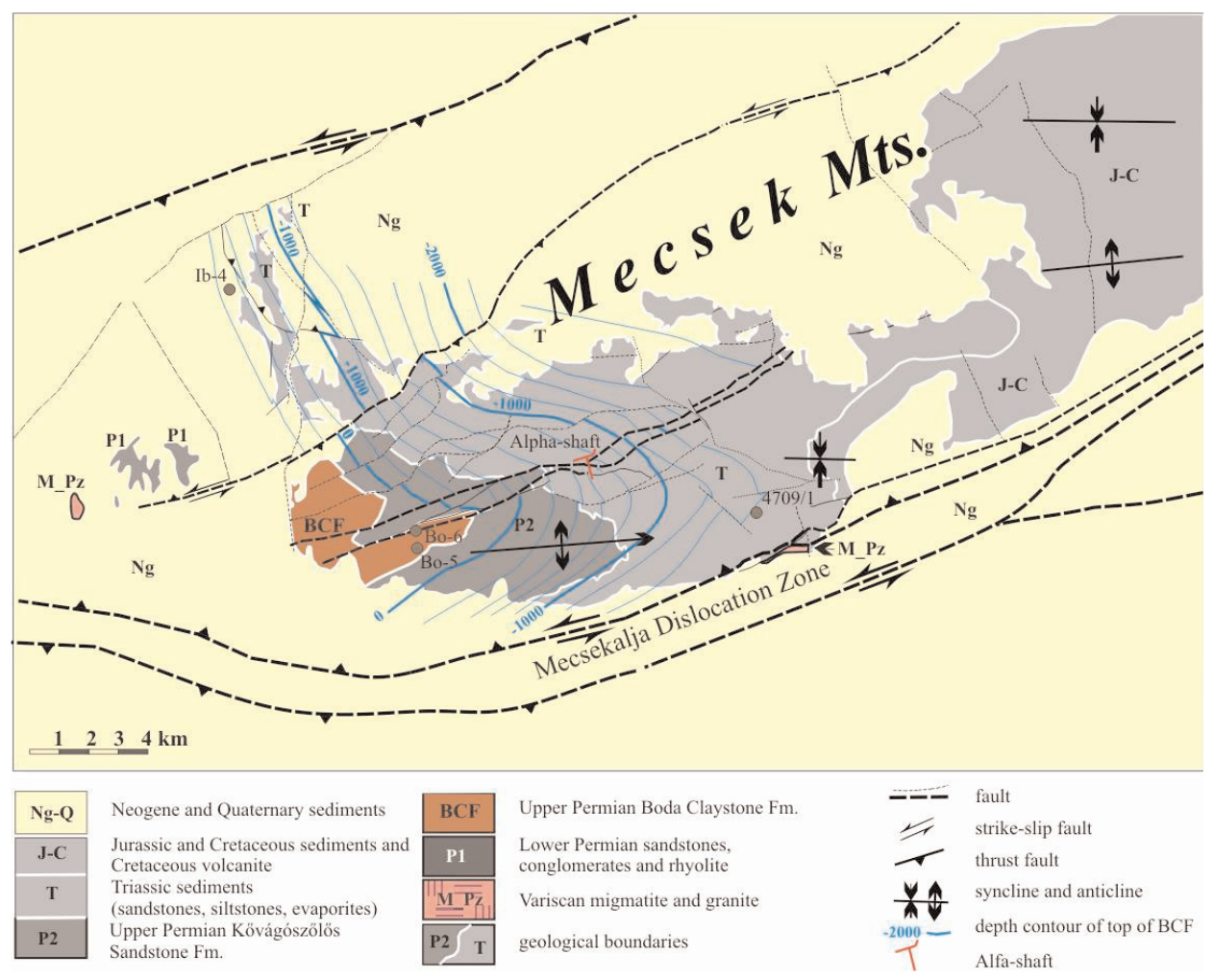

Fig. 1

Geologic map with depth contours of the top of the BCF (after Konrád et al. 2010)

detailed laboratory analyses the dominant rock type of the formation is not siltstone (as recorded by the old name of the formation) but albitic claystone, albitic siltstone, clayey albitolite, often with $0.1 \mathrm{~mm}$ long, less frequently with 1-3 $\mathrm{mm}$ long, irregular fissures or cavities filled by white calcite and albite. Not all rock types distinguished by laboratory analyses can be identified by the naked eye. "The most monotonous formation of the country" (Jámbor 1964) is composed of the following main rock types: sandstone, (albitic) silty claystone, (albitic) clayey siltstone, albitolite - together referred to as siltstone, limonitic, clayey siltstone, dolomite, dolomarl.

\section{Basic data}

A summary of the sequence in well Ib-4

A detailed geologic description of the BCF in the well was provided by Sebe and Sámson (2006). The continuously cored well reached the top of the BCF at 
$494.6 \mathrm{~m}$ and was terminated in the same formation at the depth of 708.6 meters. At present this is the best sequence of the formation available for study within the Gorica area (the northwestern part of the known occurrence) and shows typical differences compared to the rocks exposed and drilled within the Western Mecsek anticline.

The geologic overview is based on the manuscript of Sebe and Sámson (2006). The formation is dominated by silty claystone and clayey siltstone; the lower 60 $\mathrm{m}$ consist mostly of fine-grained sandstone. In some cases the siltstone contains significant amounts of fine sand grains and is difficult to distinguish from the fine-grained sandstone. Based on macroscopic characteristics, pure claystone could only be identified in very few places. Albitic claystone was not considered a separate category since albitic nodules could be seen along nearly the entire core. The rock is mainly uniform dark reddish-brown; if any tone change exists, then its trend depends primarily on the grain size. Green or gray colors can often be observed in scattered, 1-2 cm large, diffuse patches, in several places linked to boring traces or desiccation cracks and, in a few spots, to dolomite interbeds. Dolomite, sandstone and siltstone interbeds are light-colored, whitish, grayish or brownish.

The boundary between the layers is most frequently a gradual transition, though sharp boundaries are not uncommon, primarily at the base of sandstone layers or minor sandstone and dolomite interbeds. Some of the latter appear to be erosion surfaces. In the lower section of the core the initially sharp boundaries have also become irregular because of bioturbation, while more upsection desiccation structures disturb the lower bedding planes of the interbeds. Unconformities were not recorded anywhere. The cement is mostly carbonate; carbonate-free claystone layers occur only in the upper part of the sequence. In the lower part, several fine-grained sandstone or siltstone layers show strong carbonate concentration. The dominant grain size is clay in the upper part of the sequence; down-section silt becomes increasingly important, while in the lower, so-called "transitional beds" it is mostly fine to medium-grained sand. Dolomite interbeds are usually microcrystalline. A grain size trend is observable mainly in the lower portion of the formation and it almost exclusively indicates a finingupward tendency at various scales. Pure sandstone is usually composed of fining-upward cycles a few tens of $\mathrm{cm}$ thick; its grain size comprises all sand fractions but is typically medium-grained or finer. In the upper part of the "transitional beds", usually clayey siltstone beds and laminated fine sand siltstone - claystone successions alternate, with bed thickness ranging from a few to a few tens of $\mathrm{cm}$. The mixed successions are often built up of $0.5-1 \mathrm{~cm}$ thick microcycles with a sharp base but gradually fining upward, while in other places they are composed of $0.5-1 \mathrm{~mm}$ thick laminae. At the base of beds/cycles also containing sandstone, conglomerate made up of a few mm-large, rounded, intraformational (claystone and fine-grained sandstone) pebbles can be observed at several locations. In the typical siltstone/claystone of the formation no bedding 
can be seen; dip data in the documentation were determined from the orientation of interbeds, albite nodules and joint surfaces. The sandstone shows plain or wavy cross-bedding; parallel horizontal bedding is also typical, but flaser beds and climbing cross-lamination occur as well. The dip of bedding planes is variable; laminae are approximately $0.5 \mathrm{~mm}$, in coarse-grained beds $1 \mathrm{~mm}$ thick.

The siltstone or claystone bulk material is interbedded with sandstone in the lower part of the borehole and by dolomite and clayey dolomite in the upper part. Above the lower, sandstone-bearing "transitional beds", for about $50 \mathrm{~m}$ the two interbed types occur together in the borehole (Fig. 2). Their thickness is usually $2-4 \mathrm{~cm}$, rarely more $(\max .10 \mathrm{~cm})$. Fossils are lacking in the formation, apart from trace fossils. These are dominant in the lower, "transitional" part and they determine the sediment structure. Further up-sequence they occur only in scattered fashion and are often linked to sandstone and dolomite interbeds.

The total gamma radiation generally increases upwards in the succession, reflecting a downward increase in grain size. This shows there is a strong correlation between the gamma-ray log and the lithology.

\section{Results}

\section{Markov analysis}

The source data came from the geologic database of borehole Ib-4 (Sebe and Sámson 2006). The Markov chain models are positioned between the extreme deterministic model (where any event exactly determines the directly following event) and the independent event model (where there is no relationship between the consecutive events) (Geiger 2007). Markov chains and Markov processes are important classes of stochastic processes. A Markov chain is a discrete-time process for which the future behavior is determined by the past and the present. An interesting way of analyzing a Markov process is through the embedded Markov chain. If we consider the Markov process only at the moments upon which the state of the system changes, and we number instances a, b, c, etc., then we obtain the Markov chain. Geologic observation can be structured as Markov chains in two main ways, both of which have been used in stratigraphic analysis. The first approach considers the lithology at discrete points that are spaced equally along the vertical section. The second approach considers only the succession of lithologies, and because each transition is to a different lithology within the system, the diagonal elements are all zero. In this paper we used the second method.

It is also necessary to examine whether the application criteria of representing the lithological composition with a Markov chain are fulfilled and whether the analysis of observation data does not contradict the one-step Markov process. The five basic criteria of applying the method (Geiger 2007) are completely fulfilled by the studied rock sequence. 


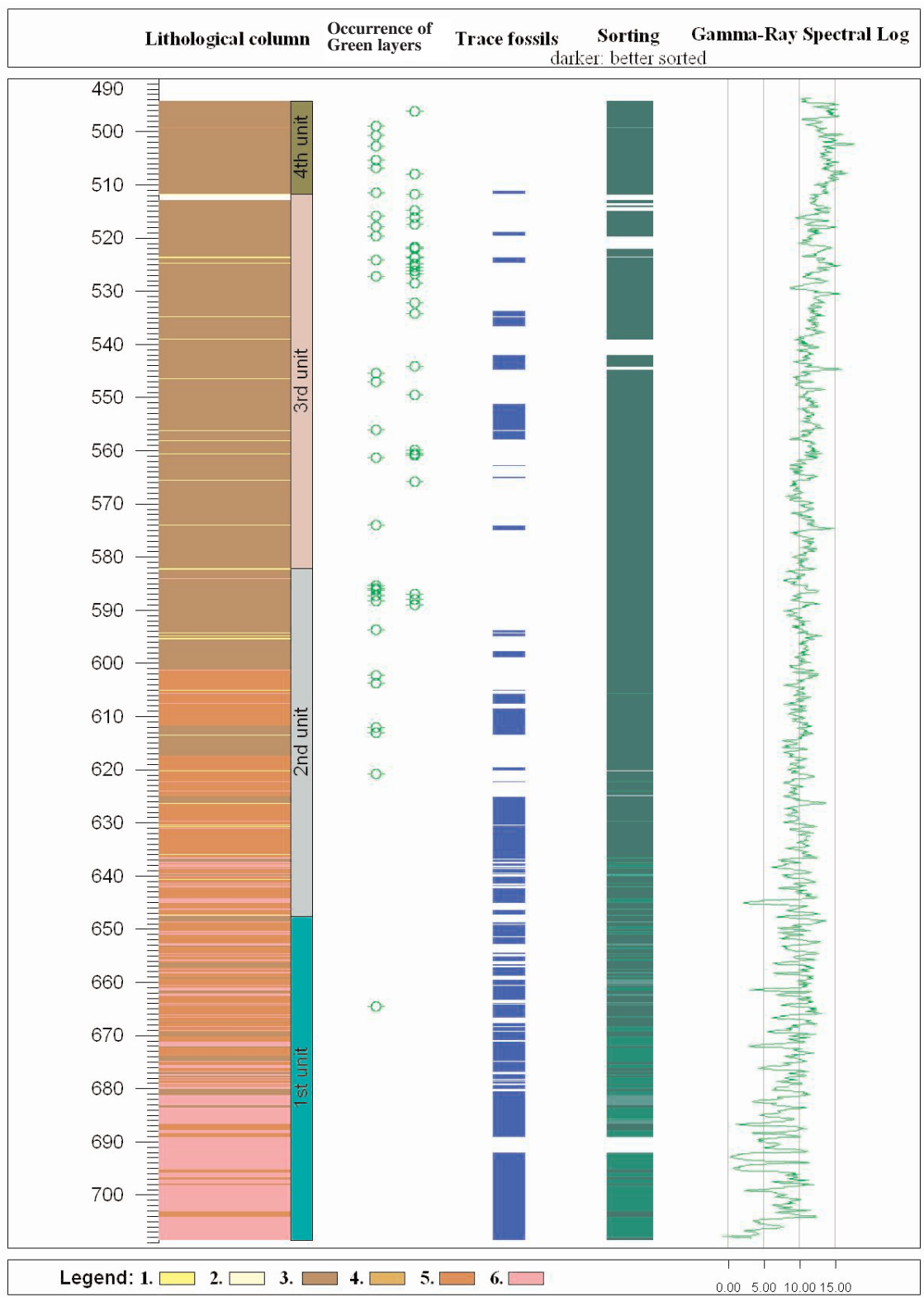

Fig. 2

Composite log of $\mathrm{Ib}-4$. The occurrence of green layers (green or greenish-gray variations of siltstone and claystone) occur only infrequently. Color alteration occurred most commonly during later reduction of the margins of breccia clasts; less frequently, in only very few cases, it appears in layers (legend: left: shapeless, right: layer). The trace fossils column shows only its occurrence not its frequency. 1 . dolomite, 2 . clayey dolomite, 3 . claystone, 4 . silty claystone, 5 . clayey siltstone, 6 . (silty) sandstone 
During the documentation, nine rock types were distinguished in borehole $\mathrm{Ib}$ 4. It was not always possible to draw a sharp boundary between the given rock types; therefore in this study we summarized them into fewer classes. From now on in the analysis of the cyclic buildup of the formation we use four types distinguished by grain size (Table 1).

With a large-scale investigation it was possible to distinguish four units. The boundary of these units was in all cases the appearance or disappearance of a dominant rock type, representing changes in the sedimentation process. The units are marked with numbers from bottom to top (Table 2) and were the basis of further analysis.

In the present study analysis was carried out with the rock types (facies)

Table 2

Units distinguished with the large-scale investigation

\begin{tabular}{|c|c|c|c|}
\hline & $\begin{array}{c}\text { Depth of top } \\
(\mathrm{m})\end{array}$ & $\begin{array}{c}\text { Depth of bottom } \\
(\mathrm{m})\end{array}$ & $\begin{array}{c}\text { Thickness } \\
(\mathrm{m})\end{array}$ \\
\hline 4 & 494.18 & 511.78 & 17.60 \\
\hline 3 & 511.78 & 582.17 & 70.39 \\
\hline 2 & 582.17 & 647.44 & 65.42 \\
\hline 1 & 647.44 & 708.57 & 60.98 \\
\hline
\end{tabular}

Table 1

Documented and summarized rock types

\begin{tabular}{|l|l|}
\hline Summarized & Documented rock type \\
\hline $\boldsymbol{\varnothing}$ & h; clay, claystone \\
\hline \multirow{2}{*}{ D } & g; dolomite \\
\cline { 2 - 2 } & f; clayey dolomite \\
\hline C & e; silty claystone \\
\hline \multirow{2}{*}{ B } & d; clayey siltstone \\
\cline { 2 - 2 } & c; sandy clayey siltstone \\
\hline \multirow{2}{*}{ A } & b; silty sandstone \\
\cline { 2 - 2 } & a; sandstone \\
\hline
\end{tabular}

classified into the above-mentioned four categories (A; sandstone, B; siltstone, $\mathrm{C}$; claystone and $\mathrm{D}$; dolomite). The transition count (Fij), independent trials (Tij) and the difference (Dij) matrices of the Boda Formation facies states are summarized in Table 3. The computed values of chisquare exceed the limiting value at the $0.1 \%$ significance level, suggesting the presence of Markovity and cyclic arrangement of facies states. The facies relationships diagram (Table 3) is constructed from the difference matrix results.

Two major facies transition successions can be identified from the facies relationships diagram, which are sandstone to siltstone transition and dolomite to claystone facies transition successions. The sandstone to siltstone facies succession has a genetic relationship with the dolomite to claystone facies succession, but the latter sometimes appears separately. The excess of transition probability of $\mathrm{A}$ to $\mathrm{D}$ and $\mathrm{D}$ to $\mathrm{A}$ over random transition are 0.1 and 0.4 , respectively, which indicate frequent sediment influx leading to the interfingering of dolomite (drying out events) by claystone (semiarid climate). The excess of transition probability of $\mathrm{B}$ to $\mathrm{A}$ and $\mathrm{D}$ to $\mathrm{C}$ over random transition are -0.4 and -0.1 , which indicates no relationship between them; in fact siltstone very rarely covers claystone. Sandstone is usually overlain by siltstone (0.2) and hardly ever by dolomite (except in one case where clayey dolomite is underlain by clayey silty sandstone). Considering the entire sequence, the consecutive rock 
Table 3

Markov matrices and chi-square test statistics of the Boda Formation (borehole Ib-4)

\begin{tabular}{|c|c|c|c|c|c|c|c|c|c|}
\hline \multicolumn{5}{|c|}{ Transition count matrix (Fij) } & \multicolumn{5}{|c|}{ Transition probability matrix $(\mathrm{Pij})$} \\
\hline & A & $B$ & C & D & & $A$ & B & C & D \\
\hline A & 0 & 6 & 24 & 12 & A & 0.0 & 0.1 & 0.6 & 0.3 \\
\hline $\mathrm{B}$ & 6 & 0 & 100 & 14 & $\mathrm{~B}$ & 0.1 & 0.0 & 0.8 & 0.1 \\
\hline C & 23 & 100 & 0 & 1 & C & 0.2 & 0.8 & 0.0 & 0.0 \\
\hline D & 13 & 14 & 0 & 0 & $\mathrm{D}$ & 0.5 & 0.5 & 0.0 & 0.0 \\
\hline \multicolumn{5}{|c|}{ Independent trials matrix $\left(T_{i j}\right)$} & \multicolumn{5}{|c|}{ Difference matrix $\left(D_{i j}\right)$} \\
\hline A & $\begin{array}{c}A \\
6.5\end{array}$ & $\begin{array}{c}B \\
26.1\end{array}$ & $\begin{array}{c}C \\
27.6\end{array}$ & $\begin{array}{c}D \\
4.0\end{array}$ & A & $\begin{array}{c}A \\
-0.2\end{array}$ & $\begin{array}{c}B \\
-0.1\end{array}$ & $\begin{array}{l}C \\
0.3\end{array}$ & $\begin{array}{c}D \\
0.1\end{array}$ \\
\hline B & 18.6 & 74.6 & 78.7 & 11.3 & B & -0.4 & -0.6 & 0.2 & -0.3 \\
\hline C & 19.2 & 77.1 & 81.4 & 11.7 & C & -0.3 & 0.2 & -0.7 & -0.4 \\
\hline D & 4.2 & 16.8 & 17.7 & 2.5 & $\mathrm{D}$ & 0.4 & 0.4 & -0.1 & -0.1 \\
\hline \multicolumn{10}{|c|}{ Test of significance } \\
\hline \multicolumn{3}{|c|}{$\begin{array}{l}\text { Computed value } \\
\text { of } x^{2}\end{array}$} & \multicolumn{2}{|c|}{ Degrees of freedom } & & \multicolumn{4}{|c|}{$\begin{array}{c}\text { Limiting value of } x^{2} \text { at } 0.1 \% \\
\text { significance level }\end{array}$} \\
\hline \multicolumn{3}{|c|}{266.3} & \multicolumn{2}{|r|}{8} & & \multicolumn{4}{|c|}{26.1} \\
\hline
\end{tabular}

Legend: see Table 1

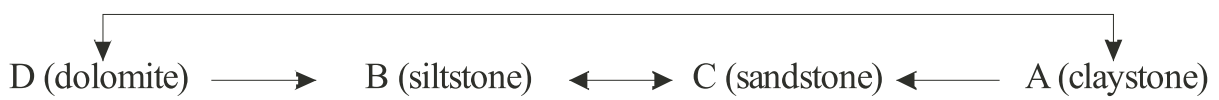

Fig. 3

Facies relationship diagram of the entire section of the Boda Formation

"pairs" dolomite-siltstone and claystone-dolomite have the highest probability of occurrence (Fig. 3).

The analysis to obtain the cycle characteristic for the given interval was carried out for three units (the fourth is too short to be analyzed). Here the processing method allowed us to use the seven rock types dominating the studied sequence (Table 1).

Markov analysis of the 1st unit

The transition count $\left({ }_{\mathrm{Fij}}\right)$, independent trials $\left(\mathrm{T}_{\mathrm{ij}}\right)$ and the difference $\left(\mathrm{D}_{\mathrm{ij}}\right)$ matrices of the Boda Formation facies states are summarized in Table 4. The computed values of chi-square exceed the limiting value at the $0.1 \%$ significance level, suggesting the presence of Markovity and cyclic arrangement of facies 
Table 4

Markov matrices and chi-square test statistics of the Boda Formation (borehole Ib-4 1st unit)

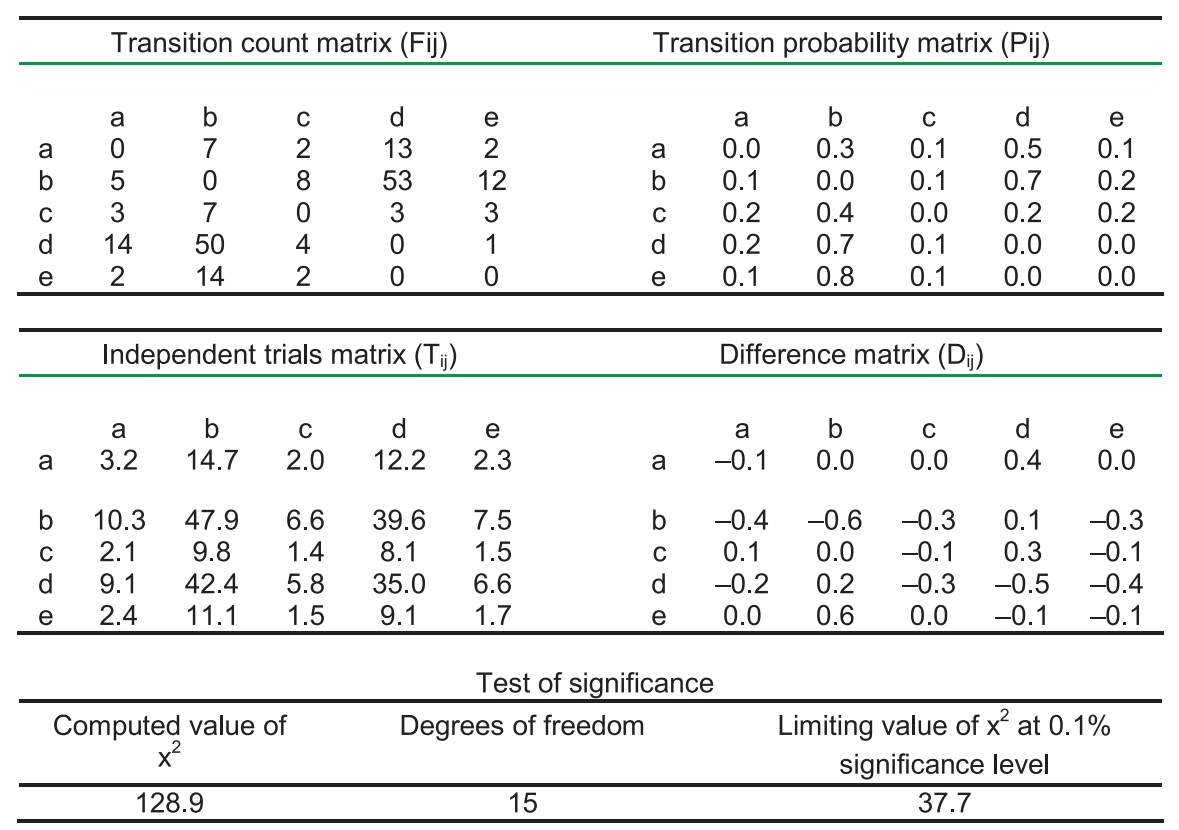

Legend: see Table 1

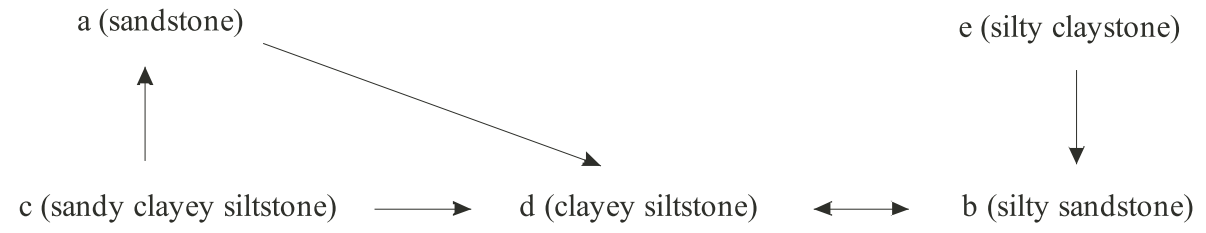

Fig. 4

Facies relationship diagram of the 1st unit of the Boda Formation

states. The facies relationships diagram (Fig. 4) is constructed from the difference matrix results. The cyclicity (Markovian property) of facies states has been tested by chi-square statistics proposed by Billingsley (1961).

The unit is composed of five types altogether. The two most frequents beds are made up of silty sandstone (78 beds) and clayey siltstone (69 beds). The other three are represented by $20-20$ beds on average. Starting from the sandy clayey siltstone a three or five-member cycle can be seen (Fig. 4). 
The unit comprises two major facies transitions from silty claystone (e) to silty sandstone (b) (the excess of transition probability: 0.6) followed by sandstone (a) to clayey siltstone (d) with the excess of transition probability: 0.4 . With any of the beds chosen as a base, cycles of four or more members are improbable according to the analysis. After the second or third step, the alternation of the two most frequent beds $(b, d)$ will dominate in nearly all cases. Therefore rhythms and incomplete cycles of 2-3 members are basically built up of sandstone and siltstone intervals. This vertical transition sequence indicates that the depositional environment changed from relatively low to relatively high energy conditions and vice versa.

\section{Markov analysis of the 2 nd unit}

The transition count (Fij), independent trials (Tij) and the difference (Dij) matrices of the Boda Formation facies states are summarized in Table 5. The computed values of chi-square exceed the limiting value at the $0.1 \%$ significance level, suggesting the presence of Markovity and cyclic arrangement of facies states. The facies relationships diagram (Fig. 5) is constructed from the difference matrix results.

All types are present except for the sandy clayey siltstone. Here also the clayey siltstone and the silty sandstone occur most frequently. Compared to the previous unit, dolomite beds are the new component here.

Two major facies transition successions can be identified from the facies relationships diagram, which are a sandstone (a) to clayey siltstone (d) transition and a (clayey) dolomite ( $\mathrm{g}, \mathrm{f}$ ) to siltstone (d) and/or claystone (e) facies transition successions. The excess of transition probability of "a" to "d" and "g" to "e" over random transition are 0.6 and 0.7 , which indicate the highest probability of the

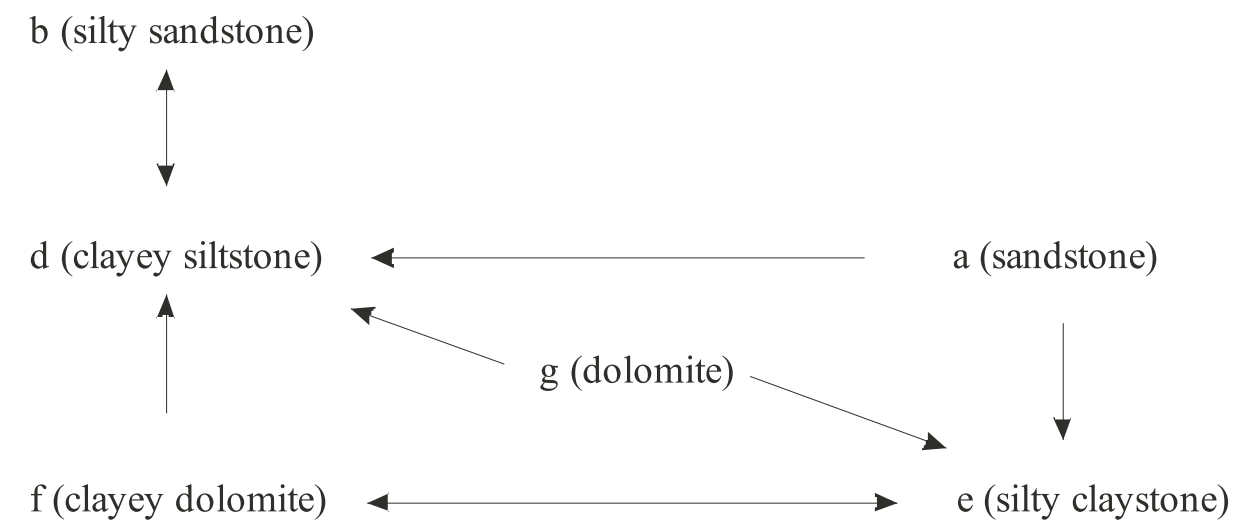

Fig. 5

The facies relationship diagram of the 2nd unit of the Boda Formation 
Cycles and rhythms within the Boda Claystone Formation in WELL Ib-4 335

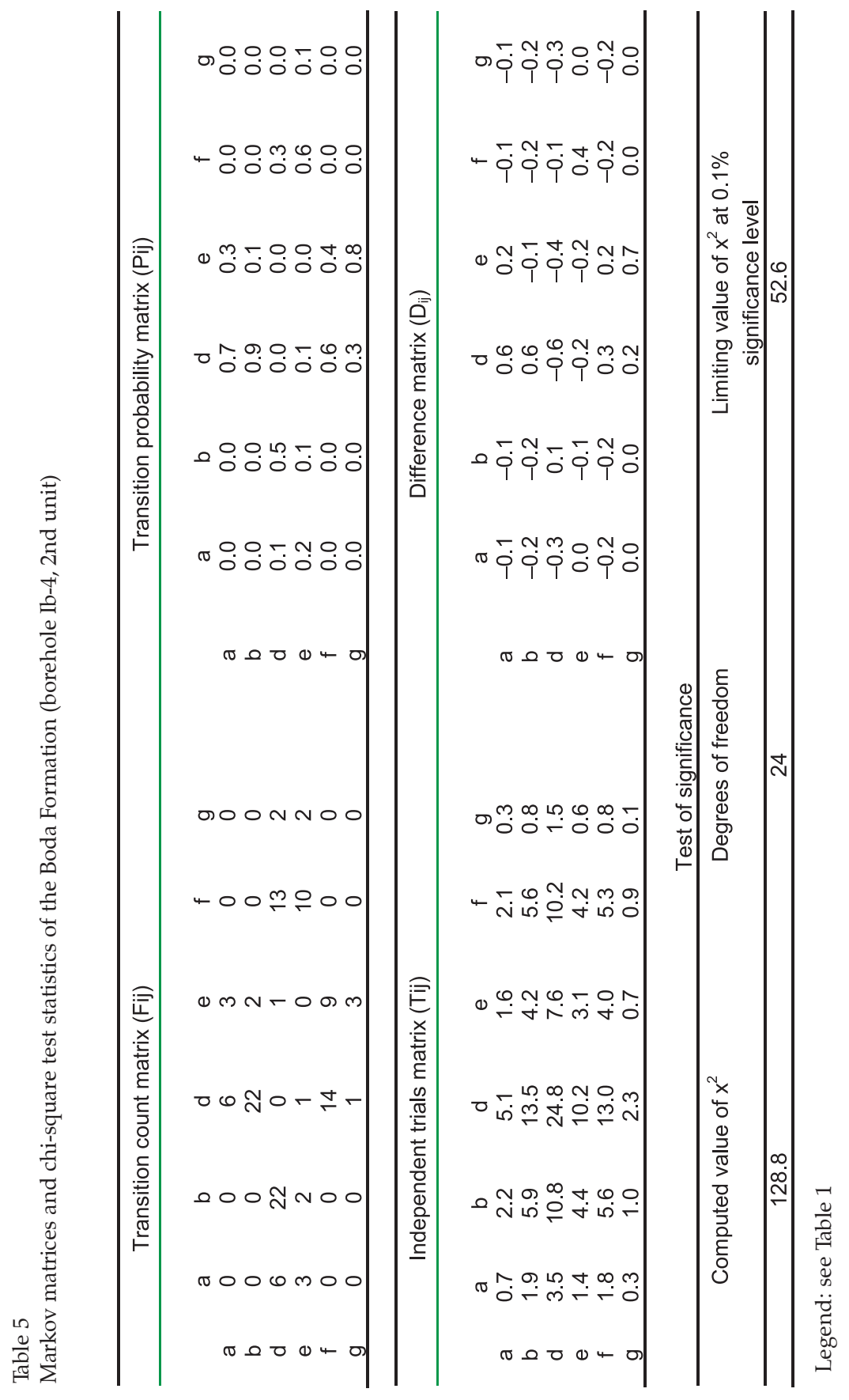

Central European Geology 52, 2009 
unit. Each complete cycle starts with sandstone (a) at the base and is succeeded by silty claystone or clayey siltstone (e and d), interbedded dolomite (f or g) and in some cases terminates with claystone at the top. These transitions construct a fining-upward sequence, indicating lower energy condition. This unit is often dominated by transitions from (clayey) dolomite (g and f) to silty claystone (e). These transitions indicating a partial or complete drying out of the lake, commonly occurred after the formation of carbonate mud by evaporation.

\section{Markov analysis of the $3 r d$ unit}

The total of 62 beds is made up of silty claystone and clayey dolomite in the same amount. Analysis showed a marked rhythmicity for the unit; this was also expected from the presence of two types.

\section{Result of the "manual processing"}

In this section the characteristic cycles of the four units and their thickness distributions are examined. The boundaries of cycles/rhythms were drawn where certain rock types reappeared or where a coarsening-upward tendency was recorded in the sequence.

1st unit (708.57-647.59 m)

The lowermost unit comprises the lower 60 meters. The upper boundary was drawn at the base of the first cycle ending with dolomite. In this sense, no theoretical cycle was found in the unit (because of the lack of dolomite). In general, nearly all rock types occur in the unit except for the dolomite. In the lower third of the unit, sandstone beds of 1-2 $\mathrm{m}$ thickness alternate with thinner clayey siltstone beds, then upsection their average thickness decreases to 10-20 $\mathrm{cm}$, or - where they occur in groups - to a few $\mathrm{cm}$. Among the increasingly frequent siltstone and silty claystone the occurrence of sandstone beds becomes less and less frequent (event-like). The analysis distinguished one cycle and three rhythm types within the 92 cycles/rhythms; AB, AC, BC and ABC (Table 6). As can be seen in the table, almost all incomplete cycles/rhythms are composed of two members. The most frequent is the alternation of siltstone overlying sandstone as well as silty claystone overlying sandstone. The expected most complete cycle occurred only three times. The thickness of cycles is $1-6 \mathrm{~m}$ in the lower $20 \mathrm{~m}$, while it is in a range of $0.06-1.74 \mathrm{~m}$ in the upper part. The average thickness is $30-40 \mathrm{~cm}$. 
Table 6

Thickness distribution of cycles/rhythms in the 1st unit

\begin{tabular}{|l|c|c|c|}
\hline & $\begin{array}{c}\text { Number of } \\
\text { cycles/rhythms }\end{array}$ & $\begin{array}{c}\text { Average } \\
\text { thickness }(\mathrm{m})\end{array}$ & Min/max thickness $(\mathrm{m})$ \\
\hline $\mathrm{AB}$ (sandstone/siltstone) & 73 & 0.59 & $0.06 / 6.87$ \\
\hline $\mathrm{AC}$ (sandstone/claystone) & 17 & 0,73 & $0.07 / 3.55$ \\
\hline $\mathrm{BC}$ (siltstone/claystone) & 1 & 1.74 & 1.74 \\
\hline $\mathrm{ABC}$ (sandstone/siltstone/claystone) & 3 & 1.45 & $1.18 / 1.99$ \\
\hline
\end{tabular}

\section{2nd unit (647.59-582.17 m)}

The second unit is also nearly 60 meters $(65.26 \mathrm{~m})$ thick. Boundaries also reflect changes in the sedimentation process. The lower boundary is the base of the first cycle ending with dolomite while the upper one is the top of the last documented cycle beginning with sandstone. In this unit all rock types occur except for the sandy clayey siltstone; therefore the occurrence of the theoretical cycle is also expected here. The sequence shows a definite fining-upward tendency. In the lower part frequent alternation of sandstone and siltstone can be observed, while in the upper part the thickness of clayey siltstone beds increases. The number of dolomitic interbeds increases upsection while that of sandstone beds decreases. Dolomite beds are surrounded by 1-5 m thick siltstone levels, in the younger part by silty claystone. In summary two important characteristics should be noted: firstly the increasing number of dolomite interbeds and the proportionally decreasing number of sandstone ones, secondly the fining-upward tendency of the sequence.

Table 7

Thickness distribution of cycles/rhythms in the 2nd unit

\begin{tabular}{|l|c|c|c|}
\hline & $\begin{array}{c}\text { Number of cycles/ } \\
\text { incomplete cycles }\end{array}$ & $\begin{array}{c}\text { Average } \\
\text { thickness }(\mathrm{m})\end{array}$ & Min/max thickness $(\mathrm{m})$ \\
\hline $\mathrm{AD}$ (sandstone/dolomite) & 1 & 0.30 & 0.30 \\
\hline $\mathrm{AC}$ (sandstone/claystone) & 2 & 0.28 & $0.19 / 0.37$ \\
\hline $\mathrm{AB}$ (sandstone/siltstone) & 22 & 0.72 & $0.10 / 3.92$ \\
\hline $\mathrm{BD}$ (siltstone/dolomite) & 9 & 1.13 & $0.16 / 3.19$ \\
\hline $\mathrm{CD}$ (claystone/dolomite) & 9 & 1.58 & $0.13 / 4.48$ \\
\hline $\begin{array}{l}\mathrm{ABD} \\
\text { (sandstone/siltstone/dolomite) }\end{array}$ & 6 & 1.28 & $0.23 / 2.99$ \\
\hline $\begin{array}{l}\text { ACD } \\
\text { (sandstone/claystone/dolomite) }\end{array}$ & 4 & 2.39 & $0.75 / 5.89$ \\
\hline
\end{tabular}




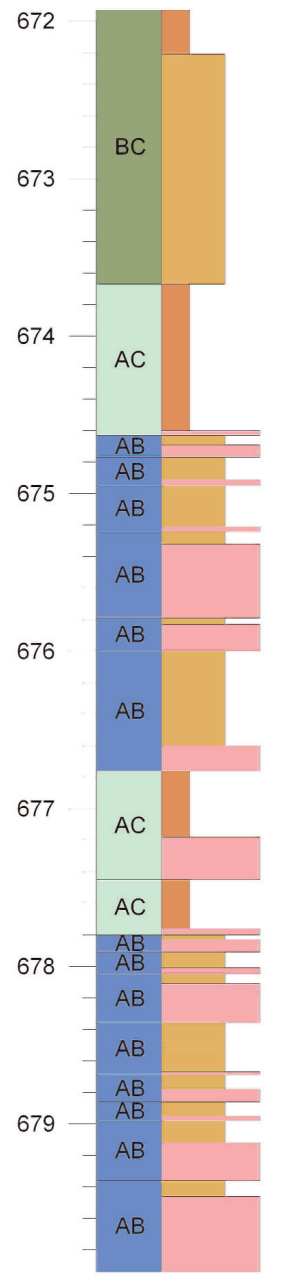

Typical cycles of the 1st unit

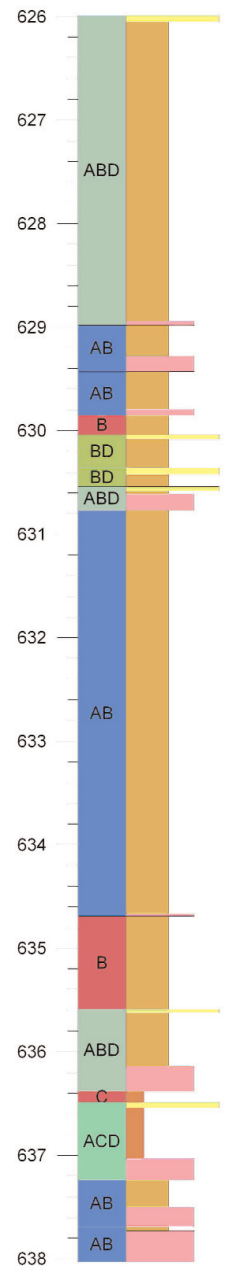

Typical cycles of the 2nd unit

Fig. 6

Typical cycles of the 1st and the 2nd units. Legend: The left columns show the cycles/rhythms types and the right columns show the lithology (same legend as Fig. 2)

Sixty-four cycles of seven types were distinguished in the unit (Table 7). The most frequent one was rhythm $\mathrm{AB}$, explained by the numerous thin sandstone beds in the lower part of the sequence. The two second most frequent types were $\mathrm{BD}$ and $\mathrm{CD}$, where dolomite also appears, indicating desiccation. Rhythms $\mathrm{AD}$ and $\mathrm{AC}$ only occur in the lower part (Fig. 6). Only 10 subunits were found that could be called cycles. The successions ABD and ACD are the most complete because they proceed from sandstone to dolomite. 
Symmetrical cycles were found mainly in the $\mathrm{BD}(\mathrm{B})$ and the $\mathrm{ABD}(\mathrm{B})$ successions, less frequently in the $\mathrm{CD}(\mathrm{C})$ and $\mathrm{ACD}(\mathrm{C})$ forms. Considering differences in the average thickness values of cycles/incomplete cycles it can easily be seen that the decrease in average grain size is accompanied by an increase in cycle thickness.

3rd unit (582.17-511.78 m)

The third major unit is 70 meters thick. The lower boundary was determined from the previous unit, the upper one was marked by the last dolomite layer. The unit is composed of 4 rock types, but of these claystone and "pure" dolomite only appear once. In all other cases an alternation of silty claystone and clayey dolomite can be observed. Therefore we cannot speak of an ideal cycle here; actually only one rhythm type builds up the entire unit. It is well visible in the sequence that the claystone intervals, typically several meters thick, are interbedded by a few centimeter-thick dolomite layers. In three or four cases dolomite groupings can be observed, where the thickness of internal silty claystone levels does not exceed $10-20 \mathrm{~cm}$. The alternation of dolomite and claystone beds within these groupings was considered to be separate rhythms because their summarized interpretation requires further study.

Thirty-three rhythms were distinguished in the unit; of these only one "does not fit", where silty claystone is followed by claystone and then by clayey dolomite. In all other cases the silty claystone - clayey dolomite pair is seen. The average thickness of rhythms is $2.14 \mathrm{~m}$, which conceals the difference between the two extremes $(0.07 / 7.21 \mathrm{~m})$. The low values are due to the very short cycles in the dolomite groupings.

4th unit $(511.78-494.18 \mathrm{~m})$

The thickness of the fourth unit barely exceeds 17 meters. The seven layers of the unit do not show a definite cyclicity, except for the uppermost $12 \mathrm{~cm}$, where a sandstone - claystone - dolomite succession can be called a complete cycle.

\section{Thickness distribution of the cycles}

Thickness values of the cycles/rhythms were also examined. The identified cycles/rhythms were the following: $\mathrm{AB}, \mathrm{ABC}, \mathrm{ABD}, \mathrm{AC}, \mathrm{ACD}, \mathrm{AD}, \mathrm{BC}, \mathrm{BD}, \mathrm{CD}$ and $C C D$. Among these were primarily considered the ones that occurred more than 10 times in the sequence; therefore the thickness distribution of the rhythms $\mathrm{AB} A C \mathrm{CD}$ was analyzed (Fig. 7). However, the thickness of AB-type rhythms shows an interesting distribution. The figure indicates that the most frequent values are below $40 \mathrm{~cm}$, and within this even below $20 \mathrm{~cm}$. The thickness of other cycle types shows a relatively even distribution (0.3-1.2 m). In the case of type CD 

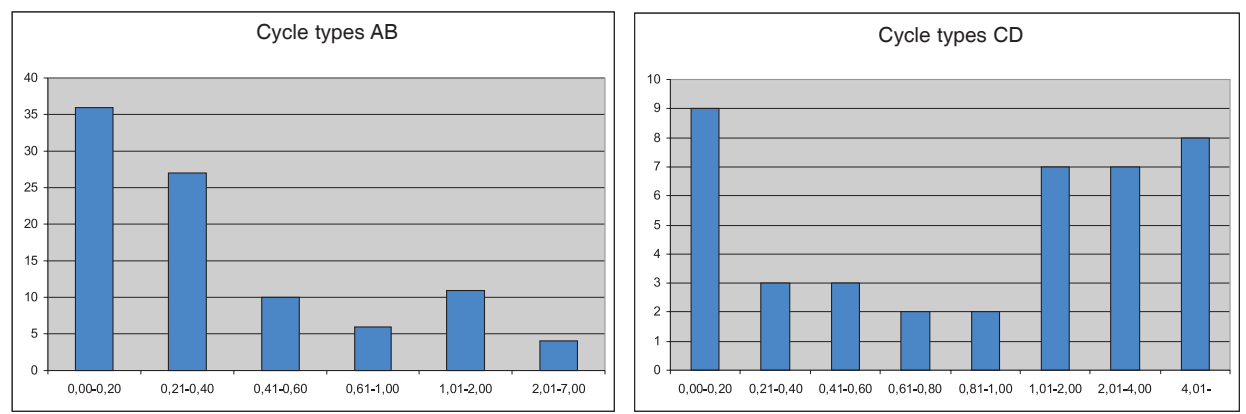

Fig. 7

Thickness distribution of the incomplete cycle types $\mathrm{AB}$ and $\mathrm{CD}$

it is interesting to note that the cycles thinner than $20 \mathrm{~cm}$ and those thicker than $1 \mathrm{~m}$ dominate (Fig. 4). The great thickness value is assumed to be the result of the long time interval between desiccation events. The few $\mathrm{cm}$-thick, incomplete cycles represent the grouped dolomite interbeds. In intervals greater than $0.5 \mathrm{~m}$ the dominant layer is claystone, since dolomite typically occurs at a scale of a few $\mathrm{cm}$.

\section{Discussion}

As we have already seen, the ideal cycle is composed of three or four members, where in many cases, within the sandstone - siltstone - claystone - dolomite succession, one of the two internal members does not appear. Within the ideal cycle, 2-member incomplete cycles and rhythms occur, which can be observed anywhere in the formation. In incomplete cycles characteristically the lower or upper member is missing; these cycles can be called incomplete below or above. The most common incomplete cycles have two members; however, these can be considered part of a bigger cycle and are thus not called rhythms. From a cycle stratigraphic aspect, the formation can be divided into 3 units and the cycle and rhythm types are clearly related to the individual units. In the lower part of the sequence, characteristic cycles are incomplete on top because of the lack of dolomitic layers. In the middle part all three types of cycles occur. This is the unit where ideal cycles occur most frequently; from bottom to top the number of incomplete cycles increases, with the number of cycles incomplete at the top decreasing. In the youngest unit (in the upper 400-500 m) the number of ideal cycles is insignificant and the alternation of claystone/siltstone - dolomite cycle members becomes dominant. It is worth mentioning that in some cases cycles ending with dolomite are followed by the rock type underlying the dolomite and then by another cycle independent of the previous one. This may mean that after the deposition of the dolomite, the same sedimentation process continued as the one preceding it. According to Balogh (1992) this is characteristic of symmetrical cycles. 
The probability of cycles following each other was also investigated with the help of the "embedded" Markov chain method, but in several cases the high number of certain bed types distorted the results. Considering the individual units and the entire sequence, this supports the previously displayed results, namely that from bottom to top first the lack of the dolomitic cycle member, then the presence of all cycle members, and finally the lack of the lower (sandstone) member, is characteristic.

In the first unit it was noticed that among the sandstone layers, the "host rock" becomes finer-grained, i.e. if we consider the sandstone to be the product of short events, then the fining of the "host rock" is the dominant tendency in the largescale process, which becomes the object of further study. In this case sandstone cannot be considered as rhythm or cycle boundary, however, because it is not directly linked to the fining-upward tendency of the "host rock". This can be considered to be a simultaneous appearance of the auto- and allocycles or of the climatic and tectonic effects, but at different scales. The question is to what extent auto- and allocycles and tectonic and climatic forcing and consequences can be separated.

The Markov chain is distorted by the high number of some of the rock types; therefore it is necessary to examine all succession possibilities. The analysis is applicable, because we can attain a realistic image of the sequence; it is a quick and simple method, and the number of possible errors is low.

\section{Acknowledgements}

A major part of the study was carried out for the Public Agency for Radioactive Waste Management (PURAM) as part of the Boda Claystone Research Program. The authors wish to express their thanks to Gyula Konrád and János Geiger for their useful reviews and comments on the manuscript.

\section{References}

Balogh, K. 1992: Szedimentológia III. (Sedimentology III). - Akadémiai Kiadó, Budapest, 400 p. Barabásné Stuhl, Á. 1969: A mecsek-hegységi felsőpermi üledékek tagolása ciklusos kifejlődésük alapján (Subdivision of the Upper Permian sediments in the Mecsek Mts. based on their cyclicity). - Földtani Közlöny 99, pp. 66-80.

Barabásné Stuhl, Á. 1988: A Dél-Baranyai-dombság és a Villányi-hegység perm képződményeinek kutatásáról készített összefoglaló jelentés IV. fejezete a permi képződményekről (Final report of the Permian formations of the Villany Mountains and the Southern-Baranya Hills). Manuscript, Mecsekérc Zrt. Archives.

Barabás, A. 1955: A mecseki perm időszaki képződmények (The Permian formations of the Mecsek). - Kandidátusi értekezés, Manuscript 128 p.

Billingsley, P. 1961: Statistical methods in chains. - Arm. Math. Statist., 32, pp. 12-40.

Geiger, J. 2005: A CT vizsgálatok és a laboratóriumi kőzetfizikai vizsgálatok eredményeinek numerikus kiértékelése (AFENÉBE program rendszer) [Numerical evaluation of the results of $\mathrm{CT}$ and petrophysical laboratory investigations (AFENÉBE software package)]. - Mecsekérc Zrt. Archives, Pécs, 47 p. 
Geiger, J. 2007: Geomatematika (Geomathematics). - Szeged, JATEPress, pp. 13-30.

Hámos, G., Gy. Majoros, Z. Máthé 1996: The geology of Boda site, Hungary. Surface and URL based investigations. - TOPSEAL '96 Transactions, Stockholm, Vol. II., pp. 196-199.

Jámbor, Á. 1964: A Mecsek hegység alsó permi képződményei (The Early Permian formations of the Mecsek Mts). - Manuscript, Mecsekérc Zrt. Archives, Kővágószőlős, 113 p.

Konrád, Gy. 1999: The Boda Claystone Formation. - "The Geology of today for tomorrow". A satellite conference of the World Conference of Science, Budapest. Excursion Guide Book, pp. $65-75$.

Konrád, Gy., G. Hámos 2006: A magyarországi nagy aktivitású radioaktív hulladéktároló telephely kijelölésének földtani szempontjai és az eddigi kutatások eredményei (Geologic aspects of determining high activity radioactive waste depository sites in Hungary and the results of the recent research). - Acta Geographica, Geologica et Meteorologica Debrecina, 1, pp. 33-39.

Konrád, Gy., K. Sebe, A. Halász, E. Babinszki 2010: Sedimentology of a Permian Playa Lake: Boda Claystone Formation, Hungary. - Geologos, 16/1, Poland, pp. 24-41.

Majoros, Gy. (szerk.) 1999: Nagy léptékú földtani vizsgálatok, regionális tektonikai és szedimentológiai modell kidolgozása (Large-scale geologic studies, elaboration of a regional tectonic and sedimentological model). - Final report of the Short-term Investigation Program of the Boda Siltstone Formation 2. Mecsekérc Ltd. Archives, Kővágószőlős, 100 p.

Sebe, K., M. Sámson 2006: Ib-4 fúrás Bodai Aleurolit Formáció (Borehole Ib-4, Boda Claystone Formation). - Manuscript, Mecsekérc Zrt. Archives, Pécs, 16 p. 